\title{
Surface Modification of Cellulose Nanomaterial for Urea Biosensor Application
}

(Pengubahsuaian Permukaan Bahan Nano Selulosa untuk Aplikasi Biosensor Urea)

\author{
WAN Elina FARAdILla WAn KHALID, LEE YOOK HENG* \& MOHAMAd NASIR MAT ARIP
}

\begin{abstract}
Cellulose nanomaterial with rod-like structure and highly crystalline order, usually formed by elimination of the amorphous region from cellulose during acid hydrolysis. Cellulose nanomaterial with the property of biocompatibility and nontoxicity can be used for enzyme immobilization. In this work, urease enzyme was used as a model enzyme to study the surface modification of cellulose nanomaterial and its potential for biosensor application. The cellulose nanocrystal (CNC) surface was modified using 2,2,6,6-tetramethylpiperidine-1-oxyl radical (TEMPO)-mediated oxidation to introduce the carboxyl group at C6 primary alcohol. The success of enzyme immobilization and surface modification was confirmed using chemical tests and measured using UV-Visible spectrophotometer. The immobilization strategy was then applied for biosensor application for urea detection. Cyclic voltammetry $(\mathrm{CV})$ and differential pulse voltammetry (DPV) techniques were used for electroanalytical characterization of the urea biosensor.
\end{abstract}

Keywords: Biosensor; cellulose nanomaterial; enzyme immobilization; surface modification

\section{ABSTRAK}

Bahan nanoselulosa dengan struktur seperti rod dan susunan hablur yang sangat bertertib, biasanya terbentuk dengan penghapusan bahagian amorfus daripada selulosa semasa hidrolisis asid. Bahan nano selulosa dengan sifat bioserasi dan tidak toksik boleh digunakan untuk pemegunan enzim. Dalam kajian ini, enzim urease telah digunakan sebagai enzim model untuk mengkaji pengubahsuaian permukaan pada bahan nanoselulosa dan potensi untuk aplikasi biosensor. Permukaan CNC diubah suai menggunakan kaedah pengoksidaan perantara-TEMPO untuk memasukkan kumpulan karboksil pada C6 alkohol primer. Kejayaan pemegunan enzim dan pengubahsuaian permukaan ditentukan dengan menggunakan ujian kimia serta diukur menggunakan spektrofotometer Ultra-lembayung Nampak. Strategi pemegunan ini seterusnya digunakan untuk aplikasi biosensor bagi penentuan urea. Teknik voltametri siklik (CV) dan teknik voltametri denyut pembezaan (DPV) digunakan untuk pencirian elektroanalisis biosensor urea.

Kata kunci: Bahan nano selulosa; biosensor; pemegunan enzim; pengubahsuaian permukaan

\section{INTRODUCTION}

Cellulose is the most abundant material in the universe and hydrophilic in nature (Azahari et al. 2017; Kaco et al. 2017). Cellulose has many hydroxyl functional groups on its surface that can be modified using oxidation, esterification, etherification, silylation and polymer grafting methods in order to attach a new functional group for different applications (Lin et al. 2011). Modification of cellulose is able to improve the compatibility and dispersibility in different medium such as water, organic solvent and polymer matrices (Zaman et al. 2012).

Enzyme, also can be referred as protein is a macromolecule that has been widely used in the catalysis, biosensor, food industry and biotechnology fields (Sadasivuni et al. 2014). Usually it acts as a catalyst to speed up the biochemical reaction. However, enzyme stability limits its repeatable uses, thus immobilization of the enzyme can solve the instability problem ( $\mathrm{Du}$ et al. 2008). Immobilization of the enzyme usually increases the stability of the enzyme as compared to its free form. There are several types of enzyme immobilization techniques that has been widely used by researchers, including covalent bonding, adsorption and cross-linking. Usually, adsorption is much simpler and cheaper but not reusable which means the enzymes are more susceptible to leach from the matrices (Ispirli Doğaç et al. 2014). Immobilization using covalent bonding and cross-linking are more effective, but it tends to lower the enzyme activity. The crosslinking technique usually involves the uses of a cross-linking agent such as glutaraldehyde. Glutaraldehyde forms a stable cross-linking adduct by reacting with nucleophile such as amine, hydroxyl and imidazole group (Povedano et al. 2017). Immobilization by covalent bonding provides much stronger and stable bond that can avoid the leach of enzyme into the solution.

Some of the researchers used CNC for enzyme immobilization such as cyclodextrin glycosyl transferase (CGTase) and alcohol oxidase (Mahmoud et al. 2009), papain (Cao et al. 2014; Mahmoud et al. 2013), glucose oxidase (Incani et al. 2013) and Candida rugosa lipase (Kim et al. 2015). Cao et al. (2014) have used CNC magnetic composite for papain immobilization and they 
found that all the parameters studied, including $\mathrm{pH}$ stability, storage, enzyme activity and level of tolerance to organic solvent are higher in the immobilized form as compared to its free form. Study by Kim et al. (2015) found that the amount of Candida rugosa lipase enzyme adsorbed on the CNC is higher compared to cellulose material, this probably due to the nanosize of CNC which provide larger surface area as compared to cellulose. Similarly, Cao et al. (2014) demonstrated that the half-life of the enzyme immobilized on $\mathrm{CNC}$ are 27 times higher as compared to its solution form. It could become a good choice for biosensor fabrication due to good biocompatibility of the enzyme immobilized on CNC matrix. Abd Manan et al. (2016) has fabricated a phenol biosensor based on tyrosinase enzyme immobilized on $\mathrm{CNC} /$ chitosan composite film. The biosensor can detect phenol concentration in the range of $0.39-7.74 \mu \mathrm{M}$ with the LOD of $0.379 \mu \mathrm{M}$. In this work, the determination of phenol content was based on measurement of o-quinone produced from the phenol oxidation by tyrosinase enzyme. Previous studies showed that $\mathrm{CNC}$ are a good immobilization matrix for biomolecule. However, CNC conjugated-enzyme layer on the electrode surface for biosensor fabrication tends to crack when left to dry. In order to avoid or reduce the problem, CNC conjugated enzyme in the presence of poly(2hydroxyethyl methacrylate) (polyHEMA), a hydrogel has been used to ensure a good film formed at the electrode surface.

Urea that is usually monitored in the blood sample which indicates renal problem is an organic compound that consists of carbon, nitrogen, oxygen and hydrogen. The content of urea either in low or high concentration can give effect to the human health (Esmaeili et al. 2015; Hamilton \& Breslin 2014; Shalini et al. 2014). Conventional analytical methods for urea detection including gas chromatography (Miller 1971), spectrophotometry (Ceriotti \& Spandrio 1963) and colorimetry method (Beale \& Croft 1961) but all of these methods are not suitable especially for in-situ monitoring. Biosensor fabrication particularly electrochemical biosensor that could be miniaturized has been of great interest among researchers. There has been numerous urea biosensors been developed, including optical (Alqasaimeh et al. 2007), amperometric/voltammetry (Emami Meibodi \& Haghjoo 2014) and potentiometric methods (Chirizzi \& Malitesta 2011; Trivedi et al. 2009). In a study, Esmaeili et al. (2015) has developed urea optical biosensor based on nile-blue chromoionophore immobilized in kappa-carrageenan where the measurement was based on reflectance change due to the color change of the deprotonated immobilized chromoionophore. Tyagi et al. (2014) however developed an amperometric urea biosensor based on $\mathrm{NiO}$ nanorods (Nr-NiO) without employing any sensor reagent. The study involved the transfer of electron through the oxidation and reduction process of $\mathrm{Nr}-\mathrm{NiO}$ matrix through $\mathrm{Ni}^{2+}$ / $\mathrm{Ni}^{3+}$ redox couple. In addition, Saeedfar et al. (2013) fabricated a potentiometry urea biosensor based on urease immobilized in fullerene nanomaterial. The fullerene was first functionalized with carboxyl group to conjugate the enzyme where the $\mathrm{pH}$ change from hydrolysis of urea by urease enzyme was detected by a hydrogen ion ionophore that was immobilized in a polyacrylate membrane.

Generally, the enzymatic hydrolysis of urea is not an electrochemically active process. Thus, the use of $\mathrm{pH}$ sensitive redox mediators are needed for amperometry/ voltammetry analysis (Hao et al. 2015). Methylene Blue (MB) (Figure 1) is an organic dye and redox indicator that is highly dependent on pH. It is widely used as electrochemical indicator for DNA hybridization (Chen et al. 2017; Siddiquee et al. 2010; Xiao et al. 2008). In this study, MB was used as a redox mediator and the current measurement of the urea biosensor is based on the oxidation of different forms of $\mathrm{MB}$ resulted from $\mathrm{pH}$ change from the urea hydrolysis. In this study, MB was immobilized on the SPE to produce reagentless biosensor so that no need for the introduction of the redox mediator for measurement purposes.

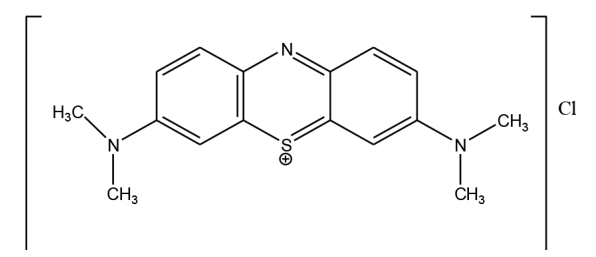

FIGURE 1. Chemical structure of methylene blue (Siddiquee et al. 2010)

Graphene that are composed of a monolayer $\mathrm{sp}^{2}$-bonded carbon atoms packed into benzene ring configuration are widely used for sensor and biosensor fabrication due to its fast electron transfer and excellent electrical conductivity (Chen et al. 2015; Gholivand \& Khodadadian 2014; Sabury et al. 2015). In our study, the reduced graphene oxide ( $\mathrm{rGO}$ ) has been used to improve the conductivity of the carbon electrode. Furthermore, it helps to facilitate the electron transfer process between the MB and the electrode surface.

In this study, urease has been used as a studied model enzyme immobilized on the modified-CNC using covalent bonding technique. TEMPO-mediated oxidation method was used for CNC surface modification and urease was immobilized on carboxylated-CNC using carbodiimide coupling method with the help of N-hydroxysuccinimide/N-(3Dimethylaminopropyl)-N'ethyl-carbodiimide hydrochloride. The potential use of the immobilized enzyme on carboxylated-CNC for urea biosensor development was evaluated.

\section{MATERIALS AND METHODS}

\section{CHEMICALS}

Cellulose nanocrystals $(\mathrm{CNC})$ and reduced graphene oxide (rGO) were provided by the Forest Research Institute 
Malaysia and Universiti Malaysia Pahang, respectively. Methylene blue, Ethyl alcohol (99.5\%), Sodium hydroxide, Sodium hypochlorite $10 \%$ from SYSTERM, N-hydroxysuccinimide (NHS), 2,2,6,6,-Tetramethylpiperidin-1-oxyle (TEMPO, 98\%), Urease, Type III: From Jack Beans, MES hydrate, poly(2-hydroxyethyl methacrylate), sodium bromide were obtained from Sigma-Aldrich, N-(3-Dimethylaminopropyl)-N' ethylcarbodiimide hydrochloride (EDC) was purchased from Fluka, Urea (ANALYTICAL UNIVAR REAGENT), Phenolphthalein (ACS, Merck), 1,4-dioxane (ACROS ORGANICS), Hydrochloric acid (37\%) from RCl Labscan. Potassium dihydrogen phosphate (SYSTERM) and Potassium phosphate dibasic anhydrous (Sigma-Aldrich) were used to prepare $0.05 \mathrm{M}$ potassium phosphate buffer (PBS). Deionized water used for solution preparation was from Thermo Scientific ${ }^{\mathrm{TM}}$ Barnstead $^{\mathrm{TM}}$ Water System.

\section{INSTRUMENTATION}

Ultra violet visible (UV-Vis) spectroscopic studies were performed using a UV-Visible Spectrophotometer Cary 50. Electroanalytical characterization was carried out by techniques using Autolab PGSTAT 12 Potentiostat (NOVA software).

\section{SURFACE MODIFICATION OF CELLULOSE NANOMATERIAL}

TEMPO-mediated oxidation method for CNC surface modification was carried out using published procedure of Sadeghifar et al. (2011) with some modification. About 250 $\mathrm{mg}$ CNC, $5 \mathrm{mg}$ TEMPO and $100 \mathrm{mg} \mathrm{NaBr}$ were suspended in $25 \mathrm{~mL}$ deionized water and were left for $30 \mathrm{~min}$ at room temperature. Next, $3.7 \mathrm{~mL} \mathrm{NaClO} 10 \%$ solution was added to the mixture. The mixture was agitated mildly for about $20 \mathrm{~min}$. About two drops of $\mathrm{NaOH} 0.5 \mathrm{M}$ was added and the solution was stirred for the duration of 24-36 h until the $\mathrm{pH}$ was maintained at $\mathrm{pH} 10-10.5$ which the reaction was considered completed. About $2.5 \mathrm{~mL}$ methanol was added to stop the reaction and the $\mathrm{pH}$ was adjusted to $\mathrm{pH} 7$ by adding $0.5 \mathrm{M} \mathrm{HCl}$. The carboxylated-CNC ( $\mathrm{CNC}-\mathrm{COOH})$ was washed for 3 times with deionized water, centrifuged at $10000 \mathrm{rpm}$ and were dried at room temperature before used.

\section{ENZYME IMMOBILIZATION ON SURFACE MODIFIED CELLULOSE NANOMATERIAL}

The immobilization of urease enzyme on CNC-COOH surface was completed using EDC and NHS. About $10 \mathrm{mg}$ each of $\mathrm{CNC}-\mathrm{COOH}$, NHS and EDC were dissolved in $5 \mathrm{~mL} 0.1$ M MES buffer pH6.5. The mixture was then stirred with magnetic stirrer for $2 \mathrm{~h}$. Urease solution was prepared in $0.05 \mathrm{M}$ PBS pH7.0. After that, $2.5 \mathrm{~mL}$ of CNC-COOH-NHSEDC mixture was mixed with $2.5 \mathrm{~mL}$ urease solution (2 $\mathrm{mg} / \mathrm{mL}$ ) and was stirred for about $30 \mathrm{~min}$. The mixture was kept overnight at $4^{\circ} \mathrm{C}$ for the immobilization to occur. $\mathrm{CNC}$ with immobilized urease was then centrifuged and washed with K-phosphate buffer pH7 $(0.05 \mathrm{M})$ at 10000 $\mathrm{rpm}$ (3 times). Urease immobilized on $\mathrm{CNC}$ was then re- dispersed into $0.5 \mathrm{~mL} \mathrm{~K}$-phosphate buffer $\mathrm{pH} 7.0$ and was kept at $4^{\circ} \mathrm{C}$ until used.

\section{LEACHING TEST AND ENZYME ACTIVITY}

After washing the immobilized urease three times with PBS pH7.0 (0.05 M), leaching test of the immobilized enzyme was carried out by re-dispersed the immobilized urease in $100 \mathrm{~mL}$ PBS pH $7.0(0.05 \mathrm{M})$. About $5 \mathrm{~mL}$ of the supernatant was taken out for every $10 \mathrm{~min}$ and placed in an empty vial. Then, the supernatant was mixed with $2.48 \mathrm{~mL} 1 \mathrm{M}$ urea solution and $20 \mu \mathrm{L} 2 \%$ phenolphthalein solution. The mixture was left to react for $30 \mathrm{~min}$ and the absorbance of the solution at $559 \mathrm{~nm}$ was measured. The same procedure was repeated for every 1 to $4 \mathrm{~h}$.

In another study, to ensure that the CNC matrix still contained immobilized urease and retained its enzyme activity after the leaching test, $100 \mathrm{~mL}$ of solution that contained immobilized urease suspended in PBS was left for $2 \mathrm{~h}$ at $4^{\circ} \mathrm{C}$. After that, the supernatant was removed and re-centrifuged at $10000 \mathrm{rpm}$ for $5 \mathrm{~min}$. Then, $600 \mu \mathrm{L} 1 \mathrm{M}$ urea and $10 \mu \mathrm{L} 2 \%$ phenolphthalein were added and kept at $4^{\circ} \mathrm{C}$ for $2 \mathrm{~h}$.

\section{ENZYME IMMOBILIZATION AND BIOSENSOR FABRICATION}

The same procedure for enzyme immobilization was used as stated previously. However, for the biosensor fabrication, about $200 \mu \mathrm{L}$ urease enzyme was taken from (4 mg/0.4 mL stock) and mixed with mixture of $\mathrm{CNC}-\mathrm{COOH}-$ EDC-NHS. Biosensor was developed using layer by layer drop coated method. First step involved a drop coated of 5 $\mu \mathrm{L}$ rGO ( $1 \mathrm{mg} / 200 \mu \mathrm{L}$ ethanol) on the SPE and was left to dry at room temperature. After that, another $2 \mu \mathrm{L}$ rGO was dropped on the SPE and was left to dry at room temperature. Next, $100 \mu \mathrm{L}$ CNC-urease dispersion was mixed with $50 \mu \mathrm{L}$ polyHEMA solution (polyHEMA was previously dissolved in $\mathrm{H}_{2} \mathrm{O}: 1,4$-dioxane, $4: 1$ ). About $10 \mu \mathrm{L}$ mixture of $\mathrm{CNC}$ urease-polyHEMA was dropped coated on the modified $\mathrm{SPE} / \mathrm{rGO}$ electrode. The MB was immobilized above 0.5 $\mathrm{cm}$ of the electrode surface by drop-coated $10 \mu \mathrm{L}$ of 40 $\mathrm{mM}$ MB in polyHEMA solution $\left(\mathrm{H}_{2} \mathrm{O}: 1,4\right.$-dioxane). The modified electrode was kept and left to dry at $4^{\circ} \mathrm{C}$ until used. Figure 2 summarizes the step-by-step fabrication of the biosensor while Figure 3 shows the SPE modification for used as a biosensor.

\section{ELECTROCHEMICAL STUDY OF UREA BIOSENSOR}

Electrochemical measurement was performed using Autolab PGSTAT 12 Potentiostat (NOVA 1.10 software). Conventional three electrodes system was used for all studies in which the modified screen-printed electrode (SPE) was employed as working electrode, glassy carbon electrode as a counter electrode and an $\mathrm{Ag} / \mathrm{AgCl}$ as a reference electrode. The electrochemical study of $\mathrm{rGO}$ and $\mathrm{rGO} / \mathrm{CNC}-\mathrm{COOH}$ modified electrode was carried out in PBS pH7.0 (0.05 M) containing MB using DPV. The effect of scan rate for $\mathrm{rGO}$ and $\mathrm{CNC}-\mathrm{rGO}$ modified electrodes 

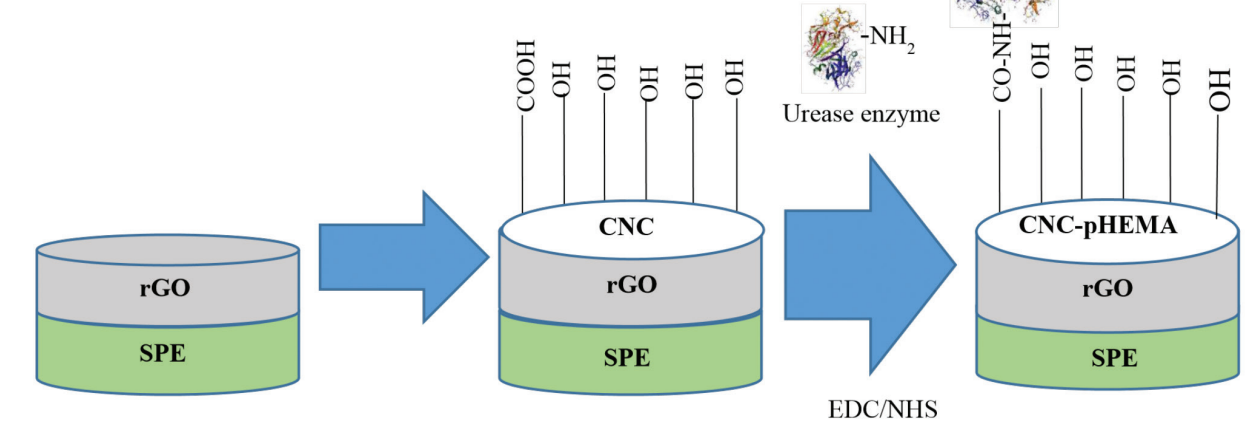

FIGURE 2. Step-by-step for biosensor fabrication

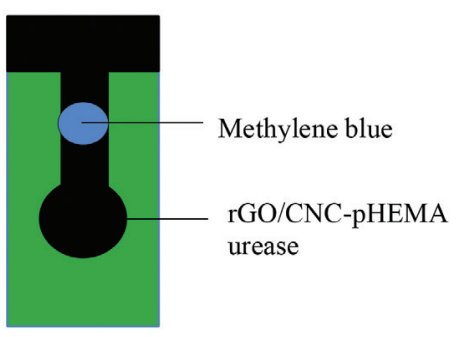

FIGURE 3. Modified electrode with urease enzyme immobilized on $\mathrm{CNC}$ and $\mathrm{MB}$ immobilized in polyHEMA coated onto carbon SPE

were measured from 10-40 mV/s. The response of the modified electrode containing immobilized urease towards different concentrations of urea in the range of $0-1.0 \mathrm{mM}$ was evaluated in PBS $0.05 \mathrm{M}$ (pH8.0). The electrochemical response was measured with equilibrium time of 5 min. The analysis will involve immobilized MB and the immobilized $\mathrm{MB}$ will be diffused into the PBS before measurement start.

\section{RESULTS AND DISCUSSION}

The surface of cellulose nanomaterial was modified using TEMPO-mediated oxidation process. The origin of cellulose nanomaterial used was from Kenaf. Acid hydrolysis process was used to produce cellulose nanomaterial. TEMPO-mediated oxidation reaction was depended on $\mathrm{pH}$ and involved a stable nitroxyl radicals, TEMPO. The reaction was optimum at $\mathrm{pH} 10-11$. The mechanism of TEMPO-mediated oxidation (Figure 4(a)) involved reactions between $\mathrm{NaClO}$ and $\mathrm{NaBr}$ to form $\mathrm{NaBrO}$. $\mathrm{NaBrO}$ which is the primary oxidant will generate TEMPO+. After that, oxoammonium was reduced to form hydroxylamine (TEMPOH) as shown in Figure 4(b). In this reaction, TEMPOH will be oxidized and $\mathrm{TEMPO}^{+}$will be recycled in the system (Buffa et al. 2016).

Immobilization of the enzyme was then completed using NHS as an activator and EDC as a coupling agent in order to activate the carboxyl group for covalent binding of the amine group of the enzyme (Raghav \& Srivastava 2016). Enzyme can be conjugated to $\mathrm{CNC}-\mathrm{COOH}$ through a nucleophilic attack of the amino group at COONHS to form amide group (Mahmoud et al. 2009). Figure 5 shows the reaction of CNC-COOH with EDC and NHS for enzyme immobilization to form amide bond.

(a)

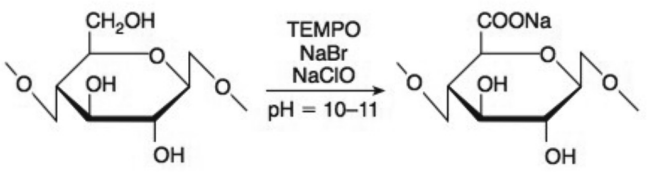

(b)

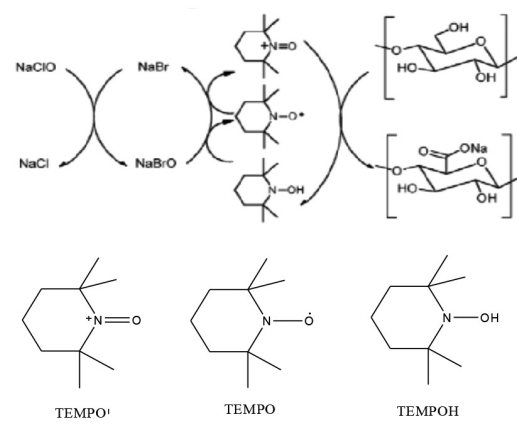

FIGURE 4.(a) TEMPO-mediated oxidation method (Isogai \& Kato 1998) (b) Reaction mechanism of TEMPO-mediated oxidation process (Buffa et al. 2016; da Silva Perez et al. 2003)

The successful surface modification of cellulose nanomaterial which leads to enzyme immobilization was first tested with UV-Vis spectrophotometer. It has been widely known that urease can hydrolyze urea to produce ammonia which can change the $\mathrm{pH}$ (1) (Luo $\&$ Do 2004). The response of the immobilized urease toward the presence of urea solution was confirmed using UV-Visible spectrophotometer. The increase of $\mathrm{pH}$ due to the production of $\mathrm{OH}^{-}$in the solution can be detected using phenolphthalein indicator. In the presence of immobilized urease and urea, phenolphthalein solution will turn to pink. This indicated that the medium became 


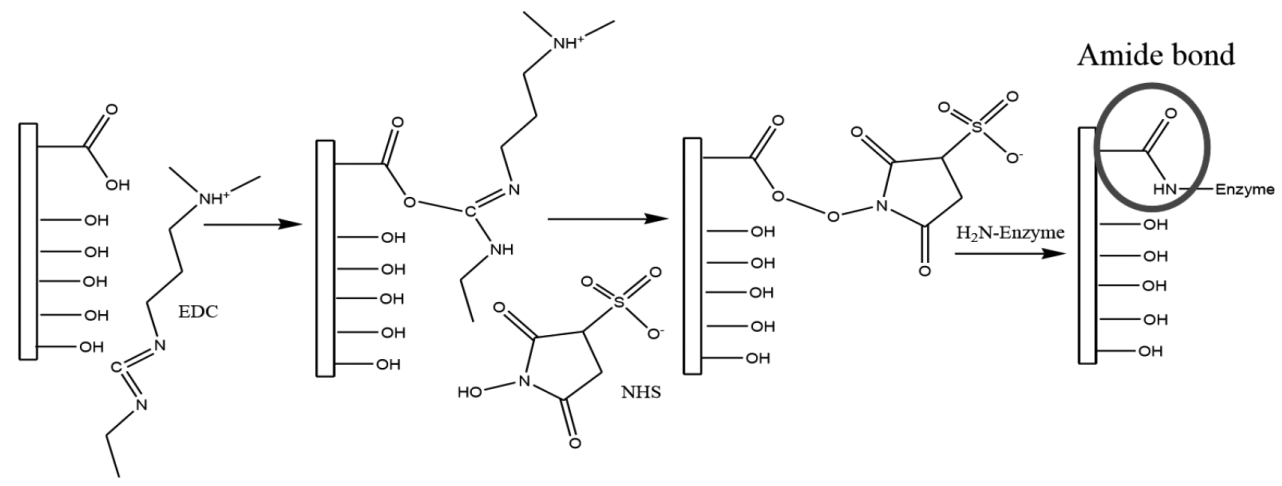

FIGURE 5. Reaction of CNC-COOH with EDC and NHS with the presence of enzyme (Janegitz et al. 2011)

more basic. Figure 6(a) shows that no absorption peak occurred during the absence of urease in the solution. However, in the presence of urease, an absorbance peak at $559 \mathrm{~nm}$ was observed.

From the leaching test results (Figure 6(b)), there was a slight increase in absorbance value for the first 30 min due to physical adsorption of enzyme onto the $\mathrm{CNC}$ matrix. However, the absorbance decreased showing that the leaching of the randomly adsorbed enzyme was decreased. No enzyme leaching was found starting at
$120 \mathrm{~min}$. After there was no leaching found in the PBS solution containing immobilized urease-CNC suspension, the immobilized urease-CNC was exposed to urea and phenolphthalein solution again. After $2 \mathrm{~h}$, the colour of the solution containing CNC matrix immobilized with urease turned to pink and thus confirming that the urease enzyme was immobilized on the $\mathrm{CNC}$ and the activity still retained after the immobilization. Therefore, the surface modification using TEMPO-mediated oxidation was considered successful.

(a)

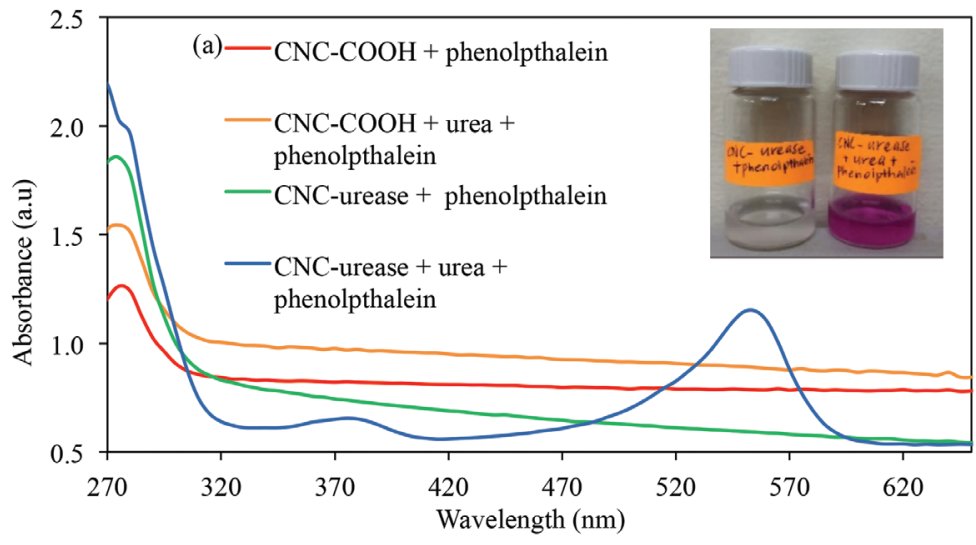

(b)

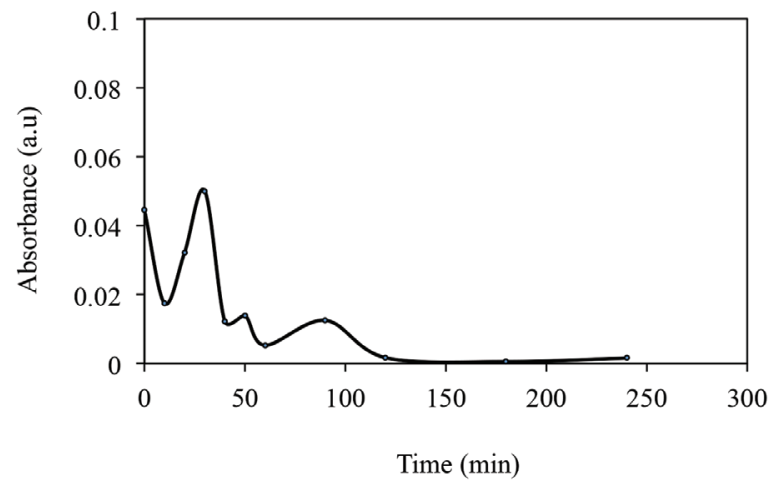

FIGURE 6. (a) Absorption spectrum of CNC-COOH without immobilized enzyme and CNC-urease in the presence of $0.1 \mathrm{M}$ urea and phenolphthalein indicator. Inset: Color change of the immobilized urease on $\mathrm{CNC}$ with the presence and absence of urea solution (b) Leaching profile of the immobilized urease at wavelength $559 \mathrm{~nm}$ 


$$
\mathrm{H}_{2} \mathrm{~N}-\mathrm{CO}-\mathrm{NH}_{2}+3 \mathrm{H}_{2} \mathrm{O} \stackrel{\text { urease }}{\longrightarrow} 2 \mathrm{NH}_{4}^{+}+\mathrm{HCO}_{3}^{-}+\mathrm{OH}^{-}
$$

After the modification and conjugation of enzyme on the surface of $\mathrm{CNC}$ has been completed, the immobilized urease on nanocellulose materials was used to construct a urea biosensor. Figure 7(a) shows the DPV of the modified electrodes in MB solution. The peak current of modified $\mathrm{SPE} / \mathrm{rGO} / \mathrm{CNC}-\mathrm{COOH}$ was reduced as compared to SPE/rGO due to the insulator properties of $\mathrm{CNC}$ where it hindered the transfer of electron at the electrode surface (Sadasivuni et al. 2014). Higher current was demonstrated by rGO and rGO-CNC modified electrode due to the presence of rGO that possess high electrical conductivity. Based on the DPV, the oxidation of MB occurred at - $0.1 \mathrm{~V}$ for SPE modified with $\mathrm{rGO}$ while $\mathrm{SPE} / \mathrm{rGO} / \mathrm{CNC}-\mathrm{COOH}$ at $-0.05 \mathrm{~V}$. The effect of scan rate of the modified electrode in MB solution showed that the current increased with the increasing scan rate (Figure 7(b)). The CV showed that the peaks for MB were obtained around $-0.1 \mathrm{~V}$ to $+0.5 \mathrm{~V}$ and there was a slight difference in the potential for CV and DPV possibly due to the electropolymerization process of $\mathrm{MB}$ at the surface of the electrode. To explain such behaviour, it has been reported that the electropolymerization of MB at polymer-modified electrode shows that the peaks at negative potential was due to the oxidation of MB monomer while for the positive potential due to the polymer formation. At first, there were a few peaks and the first anodic peak appeared at negative potential. As electropolymerization proceed, the anodic peak was reduced, and a peak appeared at positive potential (Braun et al. 2017; Marinho et al. 2012; Silber et al. 1996).

Plot of oxidation and reduction current versus square root of the scan rate showed a linear relationship based on Randles-Sevcik equation, $i_{\mathrm{p}}=\left(2.69 \times 10^{5}\right) n^{3 / 2} A c D^{1 / 2} v^{1 / 2}$ where $i_{\mathrm{p}}, n, A, c, D$ and $v$ refer to peak current (A), number of electrons react in the reaction ( 1 for $\mathrm{K}_{3}\left[\mathrm{Fe}(\mathrm{CN})_{6}\right]$ ), electrochemically effective surface area of the working electrode $\left(\mathrm{cm}^{2}\right)$, concentration of the reactant $(\mathrm{mol} \mathrm{cm})$, diffusion coefficient $\left(7.6 \times 10^{-6} \mathrm{~cm}^{2} \mathrm{~s}^{-1}\right.$ for $\mathrm{K}_{3}\left[\mathrm{Fe}(\mathrm{CN})_{6}\right)$ and scan rate $\left(\mathrm{V} \mathrm{s}^{-1}\right)$. The linear relationship between redox current and the square root of the scan rate indicates that the process on the surface of the electrode was diffusioncontrolled (Dai et al. 2013; Othman et al. 2016; Paz Zanini et al. 2016) (Figure 7(c)). Furthermore, the increasing of peak separation from oxidation to reduction potential with the increasing of scan rate shows that the system is
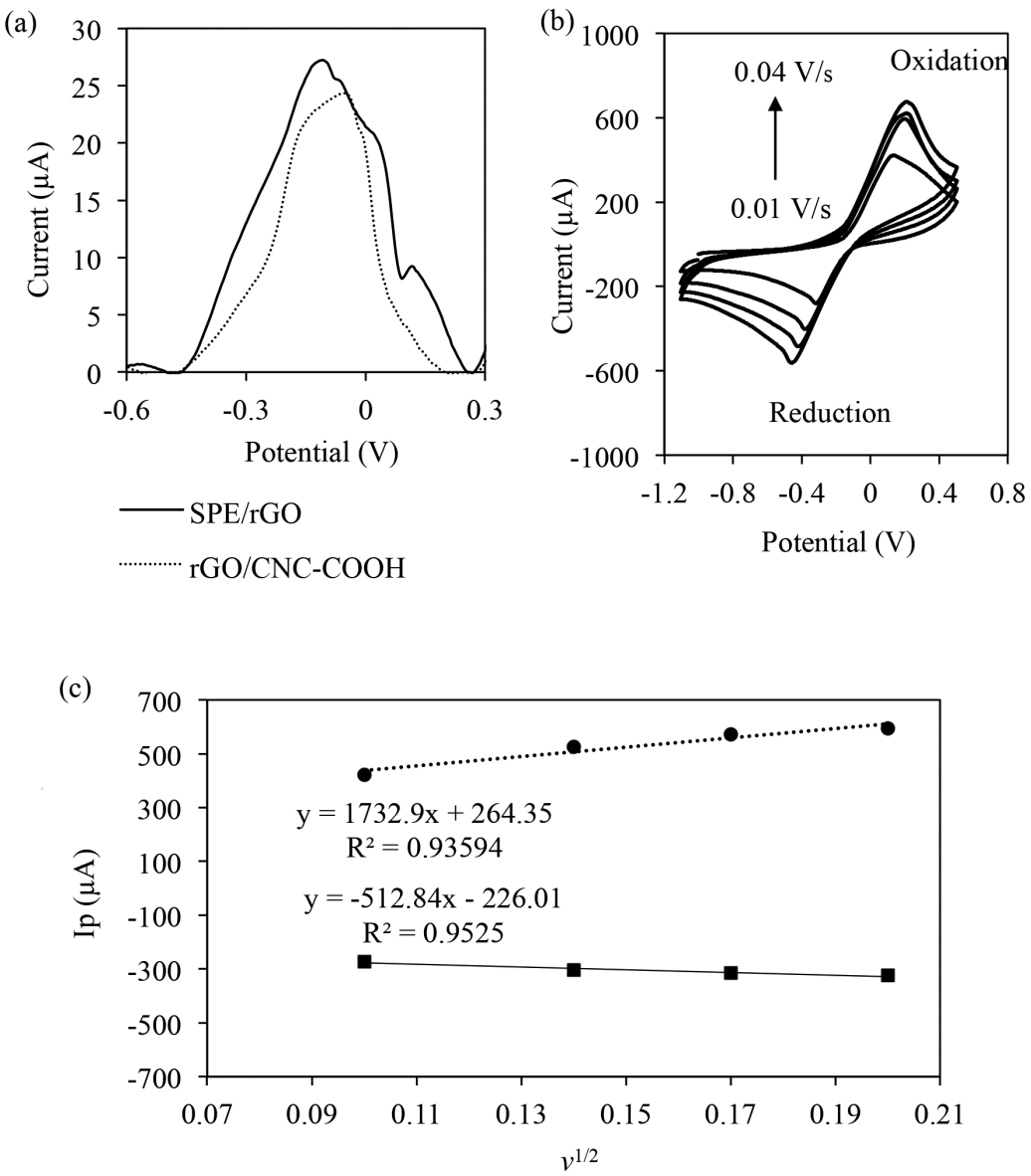

FIGURE 7. (a) DPV of modified electrode in $10 \mathrm{mM}$ MB solution (PBS $0.05 \mathrm{M}, \mathrm{pH} 7.0$ ) (b) CV of scan rate effect ( $0.01-0.04 \mathrm{~V} / \mathrm{s})$ modified electrode in PBS $0.05 \mathrm{M}, \mathrm{pH} 7.0$ containing $10 \mathrm{mM}$ MB

(c) Plot of Ipa and Ipc versus square root of the scan rate 
(a)

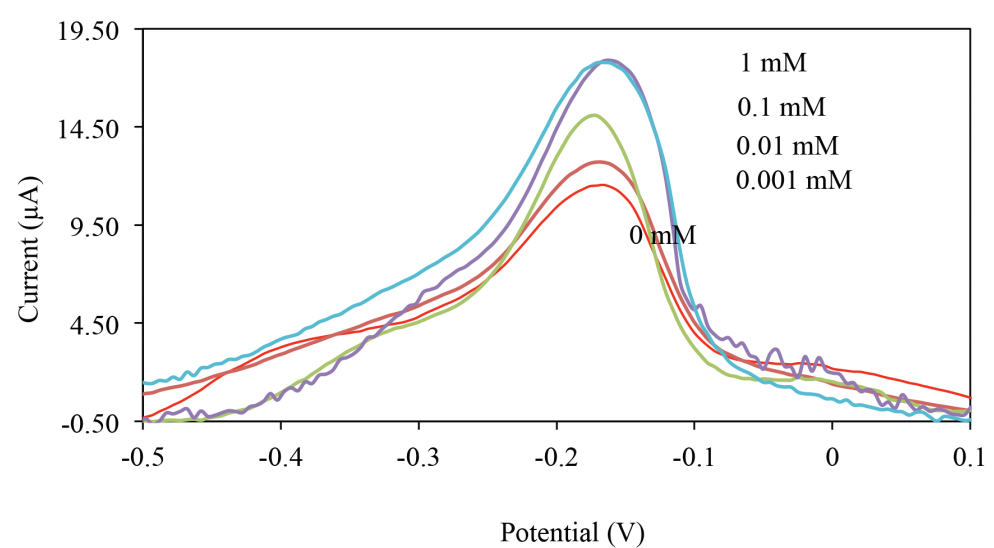

(b)

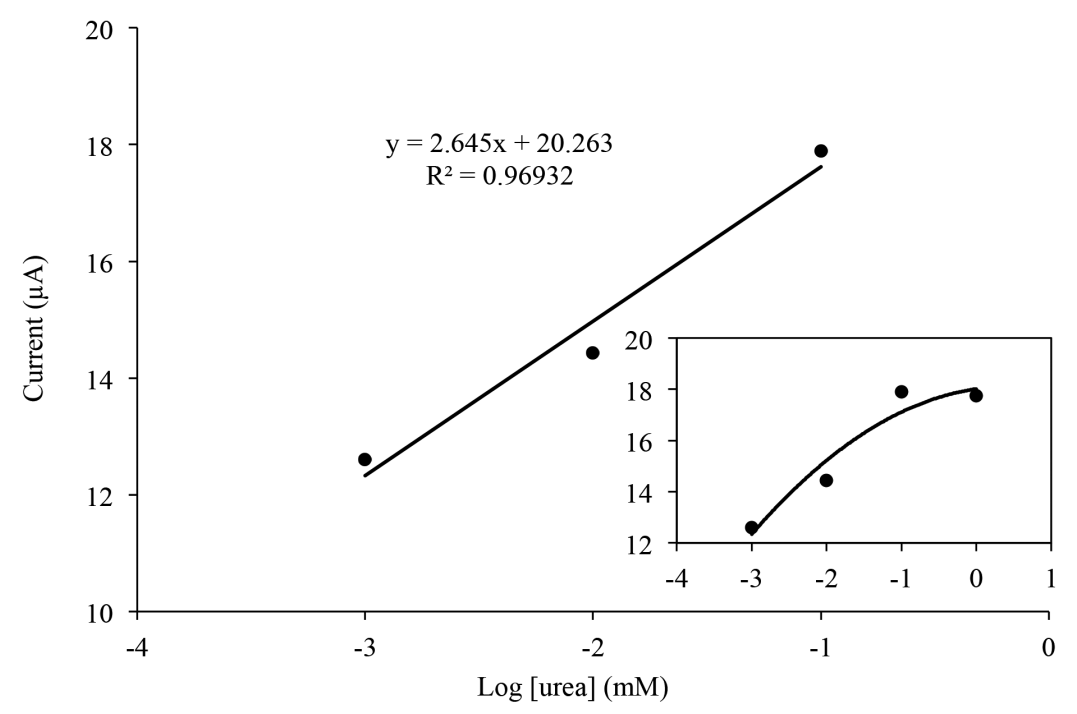

FIGURE 8. (a) The DPV response and (b) Calibration graph of current versus logarithm of urea concentrations

(Scan rate of $0.01 \mathrm{~V} / \mathrm{s}$ and equilibrium time of $10 \mathrm{~min}$ ). Inset: Current response versus logarithm of urea concentrations in the range of $0.001-1.0 \mathrm{mM}$

quasi-reversible (Tyagi et al. 2014). Figure 8(a) displays the DPV responses of the biosensor towards different concentrations $(0.001,0.01,0.1$ and $1 \mathrm{mM})$ of urea contained in PBS. The response of the biosensor increased with increasing concentrations of urea up to $0.1 \mathrm{mM}$ of urea. The trend of the biosensor response followed the kinetic enzyme and gave a linear response in the range of $0.001-0.1 \mathrm{mM}$ with $\mathrm{R}^{2}$ value of 0.9693 (Figure $8(\mathrm{~b})$ ). This confirms that the immobilized urease could function as a potential urea biosensor.

\section{CONCLUSION}

Surface modification of the CNC was carried out by attaching carboxylate group at $\mathrm{CNC}$ surface. The enzyme conjugation was completed using NHS/EDC and the enzyme was successfully immobilized on the CNC surface. This was confirmed by using UV-Visible spectrophotometry and electrochemical studies. The capability of the immobilized enzyme as a potential biosensor was successfully tested for urea detection.

\section{ACKNOWLEDGEMENTS}

The authors are grateful for the scholarship from the Ministry of Higher Education (MOHE), Malaysia. We would also like to thank Universiti Teknologi MARA for a study leave to Wan Elina Faradilla Wan Khalid to do her PhD at Universiti Kebangsaan Malaysia (UKM). We are also grateful to acknowledge the support provided by the research group DPP-2017-064 (Chemical Sensor and Biosensor UKM) and research grant UP-5179-2017.

\section{REFERENCES}

Abd Manan, F.A., Abdullah, J., Nazri, N.N., Abd Malik, I.N., Yusof, N.A. \& Ahmad, I. 2016. Immobilization of tyrosinase 
in nanocrystalline cellulose/chitosan composite film for amperometric detection of phenol. Malaysian Journal of Analytical Sciences 20(5): 978-985.

Alqasaimeh, M.S., Heng, L.Y. \& Ahmad, M. 2007. A urea biosensor from stacked sol-gel films with immobilized nile blue chromoionophore and urease enzyme. Sensors 7(10): 2251-2262.

Azahari, N.A., Sarani, Z., Kaco, H., Yee, G.S., Chia, C.H., Jaafar, S.N.S. \& Sajab, M.S. 2017. Membran selulosa kenaf terjana semula daripada larutan akues $\mathrm{NaOH} /$ urea yang digumpal menggunakan asid sulfurik. Sains Malaysiana 46(5): 795-801.

Beale, R.N. \& Croft, D. 1961. A sensitive method for the colorimetric determination of urea. Journal of Clinical Pathology 14: 418-424.

Braun, W.A., Horn, B.C., Hoehne, L., Stülp, S., Rosa, M.B.D. \& Hilgemann, M. 2017. Poly(methylene blue)-modified electrode for indirect electrochemical sensing of $\mathrm{OH}$ radicals and radical scavengers. An Acad Bras Cienc 89(3): 13811389.

Buffa, J.M., Grela,A.M., Aranguren, M.I. \& Mucci, V. 2016.EPR spectroscopy applied to the study of the TEMPO mediated oxidation of nanocellulose. Carbohydrate Polymers 136: 744-749

Cao, S.L., Li, X.H., Lou, W.Y. \& Zong, M.H. 2014. Preparation of novel magnetic cellulose nanocrystal and its efficient use for enzyme immobilization. Journal of Materials Chemistry $B$ 2: 5522-5530.

Ceriotti, G. \& Spandrio, L. 1963. A spectrophotometric method for determination of urea. Clinica Chimica Acta 8: 295-299.

Chen, G., Liu, Y., Liu, Y., Tian, Y.\& Zhang, X. 2015. Nitrogen and sulfur dual-doped graphene for glucose biosensor application. Journal of Electroanalytical Chemistry 738: 100-107.

Chen, M., Hou, C., Huo, D., Fa, H., Zhao, Y. \& Shen, C. 2017. A sensitive electrochemical DNA biosensor based on three-dimensional nitrogen-doped graphene and $\mathrm{Fe} 3 \mathrm{O} 4$ nanoparticles. Sensors and Actuators B: Chemical 239: 421-429.

Chirizzi, D. \& Malitesta, C. 2011. Potentiometric urea biosensor based on urease immobilized by an electrosynthesized poly(ophenylenediamine) film with buffering capability. Sensors and Actuators B: Chemical 157: 211-215.

da Silva Perez, D., Montanari, S. \& Vignon, M.R. 2003. TEMPOmediated oxidation of cellulose III. Biomacromolecules 4: 1417-1425.

Dai, H., Gong, L., Xu, G., Zhang, S., Lu, S., Jiang, Y., Lin, Y., Guo, L. \& Chen, G. 2013. An electrochemical sensing platform structured with carbon nanohorns for detecting some food borne contaminants. Electrochimica Acta 111: 57-63.

Du, P., Wu, P. \& Cai, C. 2008. A glucose biosensor based on electrocatalytic oxidation of NADPH at single-walled carbon nanotubes functionalized with poly(nile blue A). Journal of Electroanalytical Chemistry 624: 21-26.

Emami Meibodi, A.S. \& Haghjoo, S. 2014. Amperometric urea biosensor based on covalently immobilized urease on an electrochemically polymerized film of polyaniline containing MWCNTs. Synthetic Metals 194: 1-6.

Esmaeili, C., Yook Heng, L. \& Ling Ling, T. 2015. Nile Blue chromoionophore-doped kappa-carrageenan for a novel reflectometric urea biosensor. Sensors and Actuators B: Chemical 221: 969-977.

Gholivand, M.B. \& Khodadadian, M. 2014. Amperometric cholesterol biosensor based on the direct electrochemistry of cholesterol oxidase and catalase on a graphene/ionic liquid-modified glassy carbon electrode. Biosensors and Bioelectronics 53: 472-478.

Hamilton, A. \& Breslin, C.B. 2014. The development of a novel urea sensor using polypyrrole. Electrochimica Acta 145: 19-26.

Hao, W., Das, G. \& Yoon, H.H. 2015. Fabrication of an amperometric urea biosensor using urease and metal catalysts immobilized by a polyion complex. Journal of Electroanalytical Chemistry 747: 143-148.

Incani, V., Danumah, C. \& Boluk, Y. 2013. Nanocomposites of nanocrystalline cellulose for enzyme immobilization. Cellulose 20: 191-200.

Isogai, A. \& Kato, Y. 1998. Preparation of polyuronic acid from cellulose by TEMPO-mediated oxidation. Cellulose 5: $153-164$

Ispirli Doğaç, Y., Deveci, I., Teke, M. \& Mercimek, B. 2014.TiO2 beads and $\mathrm{TiO} 2$-chitosan beads for urease immobilization. Materials Science \& Engineering C 42: 429-35.

Janegitz, B.C., Pauliukaite, R., Ghica, M.E., Brett, C.M.A. \& Fatibello-Filho, O. 2011. Direct electron transfer of glucose oxidase at glassy carbon electrode modified with functionalized carbon nanotubes within a dihexadecylphosphate film. Sensors and Actuators B: Chemical 158: 411-417.

Kaco, H., Baharin, K.W., Zakaria, S., Chia, C.H., Sajab, M.S., Jaafar, S.N.S. \& Gan, S.Y. 2017. Preparation and characterization of $\mathrm{Fe} 3 \mathrm{O} 4 /$ regenerated cellulose membrane. Sains Malaysiana 46(4): 623-628.

Kim, H.J., Park, S., Kim, S.H., Kim, J.H., Yu, H.J., Kim, H.J., Yang, Y.H., Kan, E.S., Kim, Y.H. \& Lee, S.H. 2015. Biocompatible cellulose nanocrystals as supports to immobilize lipase. Journal of Molecular Catalysis B: Enzymatic 122: 170-178.

Lin, N., Huang, J., Chang, P.R., Feng, J. \& Yu, J. 2011. Surface acetylation of cellulose nanocrystal and its reinforcing function in poly(lactic acid). Carbohydrate Polymers 83: 1834-1842.

Luo, Y.C. \& Do, J.S. 2004. Urea biosensor based on PANi(urease)-Nafion/Au composite electrode. Biosensors and Bioelectronics 20: 15-23.

Mahmoud, K.A., Lam, E., Hrapovic, S. \& Luong, J.H.T. 2013. Preparation of well-dispersed gold/magnetite nanoparticles embedded on cellulose nanocrystals for efficient immobilization of papain enzyme. ACS Applied Materials and Interfaces 5: 4978-4985.

Mahmoud, K.A., Male, K.B., Hrapovic, S. \& Luong, J.H.T. 2009. Cellulose nanocrystal/gold nanoparticle composite as a matrix for enzyme immobilization. ACS Applied Materials and Interfaces 1: 1383-1386.

Marinho, M.I.C., Cabral, M.F. \& Mazo, L.H. 2012. Is the poly (methylene blue)-modified glassy carbon electrode an adequate electrode for the simple detection of thiols and amino acid-based molecules? Journal of Electroanalytical Chemistry 685: 8-14

Miller,P.W. 1971. Determination of urea in animal tissues by gas chromatography. Journal of Agricultural and Food Chemistry 19: 941-943.

Othman, M.A.F., Ahmad@Othman, A. \& Zuki, H.M. 2016. Dithiozone modified silver electrode for the determination of metal ions in aqueous solution. Malaysian Journal of Analytical Sciences 20: 197-204.

Paz Zanini, V.I., Gavilan, M., Lopez de Mishima, B.A., Martino, D.M. \& Borsarelli, C.D. 2016. A highly sensitive and stable glucose biosensor using thymine-based polycations into laponite hydrogel films. Talanta 150: 646-654. 
Povedano, E., Cincotto, F.H., Parrado, C., Díez, P., Sánchez, A., Canevari, T.C., Machado, S.A.S., Pingarrón, J.M. \& Villalonga, R. 2017. Decoration of reduced graphene oxide with rhodium nanoparticles for the design of a sensitive electrochemical enzyme biosensor for $17 \beta$-estradiol. Biosensors and Bioelectronics 89(Part 1): 343-351.

Raghav, R. \& Srivastava, S. 2016. Immobilization strategy for enhancing sensitivity of immunosensors: L-AsparagineAuNPs as a promising alternative of EDC-NHS activated citrate-AuNPs for antibody immobilization. Biosensors and Bioelectronics 78: 396-403.

Sabury, S., Kazemi, S.H. \& Sharif, F. 2015. Graphene - gold nanoparticle composite: Application as a good scaffold for construction of glucose oxidase biosensor. Materials Science and Engineering C 49: 297-304.

Sadasivuni, K.K., Kafy, A., Zhai, L., Ko, H.U., Mun, S. \& Kim, J. 2014. Supporting - Transparent and flexible cellulose nanocrystal/reduced graphene oxide film for proximity sensing. Small 11: 994-1002.

Sadeghifar, H., Filpponen, I., Clarke, S.P., Brougham, D.F. \& Argyropoulos, D.S. 2011. Production of cellulose nanocrystals using hydrobromic acid and click reactions on their surface. Journal of Materials Science 46: 7344-7355.

Saeedfar, K., Heng, L.Y., Ling Ling, T. \& Rezayi, M. 2013. Potentiometric urea biosensor based on an immobilised fullerene-urease bio-conjugate. Sensors 13: 16851-16866.

Shalini, J., Sankaran, K.J., Lee, C.Y., Tai, N.H. \& Lin, I.N. 2014. An amperometric urea biosensor based on covalent immobilization of urease on $\mathrm{N}_{2}$ incorporated diamond nanowire electrode. Biosensors and Bioelectronics 56: 64-70.

Siddiquee, S., Yusof, N.A., Salleh, A.B., Abu Bakar, F. \& Heng, L.Y. 2010. Electrochemical DNA biosensor for the detection of specific gene related to Trichoderma harzianum species. Bioelectrochemistry 79: 31-36.

Silber, A., Hampp, N. \& Schuhmann, W. 1996. Poly(methylene blue)-modified thick-film gold electrodes for the electrocatalytic oxidation of NADH and their application in glucose biosensors. Biosensors and Bioelectronics 11: 215-223.

Trivedi, U.B., Lakshminarayana, D., Kothari, I.L., Patel, N.G., Kapse, H.N., Makhija, K.K., Patel, P.B. \& Panchal, C.J. 2009. Potentiometric biosensor for urea determination in milk. Sensors and Actuators, B: Chemical 140(1): 260-266.
Tyagi, M., Tomar, M. \& Gupta, V. 2014. Glad assisted synthesis of $\mathrm{NiO}$ nanorods for realization of enzymatic reagentless urea biosensor. Biosensors and Bioelectronics 52: 196-201.

Xiao, M., Wang, L., Wu, Y., Huang, X. \& Dang, Z. 2008. Electrochemical study of methylene blue/titanate nanotubes nanocomposite and its layer-by-layer assembly multilayer films. Journal Solid State Electrochemistry 12: 1159-1166.

Zaman, M., Xiao, H., Chibante, F. \& Ni, Y. 2012. Synthesis and characterization of cationically modified nanocrystalline cellulose. Carbohydrate Polymers 89: 163-170.

Wan Elina Faradilla Wan Khalid \& Lee Yook Heng*, School of Chemical Sciences and Food Technology

Faculty of Science and Technology

Universiti Kebangsaan Malaysia 43600 UKM Bangi, Selangor Darul Ehsan Malaysia

Wan Elina Faradilla Wan Khalid

Faculty of Applied Science

Universiti Teknologi MARA, Negeri Sembilan

Kuala Pilah Campus, Pekan Parit Tinggi

72000 Kuala Pilah, Negeri Sembilan Darul Khusus Malaysia

Mohamad Nasir Mat Arip

Forest Products Division

Forest Research Institute Malaysia

52109 Kepong, Selangor Darul Ehsan

Malaysia

*Corresponding author; email: leeyookheng@yahoo.co.uk

Received: 14 September 2017

Accepted: 4 January 2018 